\title{
Fungal biodiversity in aquatic habitats
}

\author{
Carol A. Shearer · Enrique Descals · \\ Brigitte Kohlmeyer · Jan Kohlmeyer • \\ Ludmila Marvanová · David Padgett · David Porter · \\ Huzefa A. Raja · John P. Schmit • \\ Holly A. Thorton · Hermann Voglymayr
}

Received: 30 December 2005/ Accepted: 15 August 2006/

Published online: 27 October 2006

(C) Springer Science+Business Media B.V. 2006

\begin{abstract}
Fungal biodiversity in freshwater, brackish and marine habitats was estimated based on reports in the literature. The taxonomic groups treated were those with species commonly found on submerged substrates in aquatic habitats: Ascomycetes (exclusive of yeasts), Basidiomycetes, Chytridiomycetes, and the non-fungal
\end{abstract}

C. A. Shearer $(\bowtie) \cdot H$. A. Raja J. P. Schmit

Department of Plant Biology, University of Illinois, Room 265 Morrill Hall, 505 S. Goodwin Ave., Urbana, IL 61801, USA

e-mail: carolshe@uiuc.edu

E. Descals

IMEDEA (CSIC-UI), c. Miquel Marquдs 21, Esporles, Balears E07190, Spain

e-mail: ieaedc@uib.es

B. Kohlmeyer · J. Kohlmeyer

Institute of Marine Sciences, University of North Carolina, Morehead City, NC 28557, USA

e-mail: bjkohlm@email.unc.edu

L. Marvanová

Czech Collection of Microorganisms, Tvrdeho 14, Brno CZ-602 00, Czech Republic

D. Padgett

Biology Department, UNC-Wilmington, Wilmington, NC 28403, USA

e-mail: padgett@uncwil.edu

D. Porter $\cdot$ H. A. Thorton

Department of Botany, University of Georgia, Athens, GA 30602-7271, USA

e-mail: porter@dogwood.botany.uga.edu

H. Voglymayr

Institute of Botany, University of Vienna, Rennweg 14, Wien A-1030, Austria

e-mail: hermann.voglmayr@univie.ac.at

H. A. Raja

e-mail: raja@uiuc.edu

J. P. Schmit

e-mail: johnpauls@operamail.com 
Saprolegniales in the Class Oomycetes. Based on presence/absence data for a large number and variety of aquatic habitats, about 3,000 fungal species and 138 saprolegnialean species have been reported from aquatic habitats. The greatest number of taxa comprise the Ascomycetes, including mitosporic taxa, and Chytridiomycetes. Taxa of Basidiomycetes are, for the most part, excluded from aquatic habitats. The greatest biodiversity for all groups occurs in temperate areas, followed by Asian tropical areas. This pattern may be an artifact of the location of most of the sampling effort. The least sampled geographic areas include Africa, Australia, China, South America and boreal and tropical regions worldwide. Some species overlap occurs among terrestrial and freshwater taxa but little species overlap occurs among freshwater and marine taxa. We predict that many species remain to be discovered in aquatic habitats given the few taxonomic specialists studying these fungi, the few substrate types studied intensively, and the vast geographical area not yet sampled.

Keywords Aquatic habitats $\cdot$ Marine fungi $\cdot$ Freshwater fungi $\cdot$ Biogeography

\section{Introduction}

The ecological group covered in this paper includes fungi and taxa formerly treated as fungi, exclusive of yeasts, in freshwater, brackish and marine habitats. Representatives of all taxonomic classes of fungi and the Oomycetes (Straminipila) have been reported from aquatic habitats. Fungal species reported from aquatic habitats range from those that are adapted to complete their life cycles in aquatic habitats and are not found outside of the aquatic environment (residents) to those that occur in water fortuitously by being washed or blown in (transients). At this stage in our knowledge about the occurrence of fungi in aquatic habitats, it is often difficult to precisely characterize where species fall along this gradient of adaptation to aquatic habitats. Based on presence/absence data for a reasonably large number of aquatic habitats, however, it appears that the aquatic environment has selected against almost all basidiomycetes (e.g. of 465 species of marine fungi, only 10 are basidiomycetes). The zygomycetes are mostly absent from aquatic habitats except when the technique of dilution plating of sediments and water is used. This technique favors fast-growing species of terrestrial origin and can be misleading with respect to identifying the species of fungi active in aquatic habitats. Exceptions include the trichomycetes, which are specialized symbionts that live in the guts of aquatic arthropods and a few parasites of aquatic insects such as Erynia (Descals and Webster 1984) and Entomophthora thaxteri and Acaulopage tetraceros (Ingold 1975). Hence this paper deals exclusively with the fungal groups in aquatic habitats that occur most commonly on submerged natural substrates: chytridiomycetes, meiosporic and mitosporic ascomycetes and basidiomycetes, and the non-fungal saprolegniales of the oomycetes.

\section{Chytridiomycota, Chytridiomycetes}

The Chytridiomycota are a ubiquitous, microscopic division of fungi. The synapomorphic feature of this division is that the asexual propagule is a posteriorly, 
uniflagellate zoospore. Thus these fungi, commonly known as chytrids, thrive and reproduce in freshwater and marine environments, but also can be found commonly in habitats such as terrestrial soils where there need only be a periodic film of surface water suitable for dissemination of zoospores. The 1,250 species of chytrids that have been described are in five orders (Chytridiales, Spizellomycetales, Neocallimastigales, Monoblepharidales, and Blastocladiales). These orders are distinguished primarily on zoospore features (Barr 2001) and are supported by molecular sequence data (James et al. 2000). Many chytrids are determinate in their growth and require the production of zoospores for continued growth. Many chytrids are able to survive periods of desiccation and cold by the formation of resting sporangia.

Sparrow (1960) and Karling (1977) are the two most comprehensive references on the Chytridiomycota. Sparrow's Aquatic Phycomycetes (1960) is monographic in nature, but omits, as we do here, the large plant parasitic chytrid genera, Synchytrium (Karling 1964) and Physoderma, which together comprise 353 species. Longcore et al. (1996) created an important bibliographic update for Chytridiomycetes. Since Sparrow's monograph, two new orders of the Chytridiomycetes have been named. Barr (1980) erected the Spizellomycetales, from the Chytridiales based on zoospore ultrastructural characteristics. The anaerobic chytrids that inhabit the rumens and ceca of herbivorous mammals were discovered since Sparrow and comprise the order Neocallimastigales (Li and Heath 1993; Trinci et al. 1994; Ho and Barr 1995).

Chytrids degrade a variety of substrates, such as chitin, cellulose, and keratin, including some of the most recalcitrant materials in the biological world such as lignin and sporopollenin. They act as saprotrophs or parasites on a wide array of hosts including algae, other fungi, plants, mosses, insects and invertebrates. More recently, the first chytrid parasite of a vertebrate was described (Longcore et al. 1999). This chytrid, Batrachochytrium dendrobatidis, parasitizes and kills amphibians (Berger et al. 1999) and may be responsible, along with changes in environmental factors such as temperature (Pounds et al. 2006), for the global amphibian decline. Many genera and orders of chytrids have specificity with regard to a particular substrate and/or host.

Chytrids are found throughout the world. From our review of the literature, the majority $(80 \%)$ is found in temperate regions of the world. A smaller percentage $(55 \%)$ is found only in one location. Of the biogeographic regions designated herein, the Northern Temperate Region of the Western Hemisphere and European Temperate regions of the Eastern Hemisphere are the two areas from which most chytrids have been reported (Table 1). The abundance of chytrids from these regions is likely a result of more chytrid researchers in these regions compared to other areas. It is evident that chytrids have been under-collected in Southern Temperate and Tropical regions around the world, the Middle East, and Arctic/Antarctic regions.

\section{Freshwater meiosporic ascomycetes}

It was not until the work of C.T. Ingold $(1951,1954,1955)$ and Ingold and Chapman (1952) that specific efforts to collect freshwater meiotic ascomycetes were made. Dudka (1985a) and Shearer (1993) have summarised early reports; Goh and Hyde (1996), Hyde et al. (1997), Shearer (2001, 2002) and Cai et al. (2003) have presented more recent reviews and Cai et al. (2003) provide a taxonomic key to the commonly occurring taxa. 


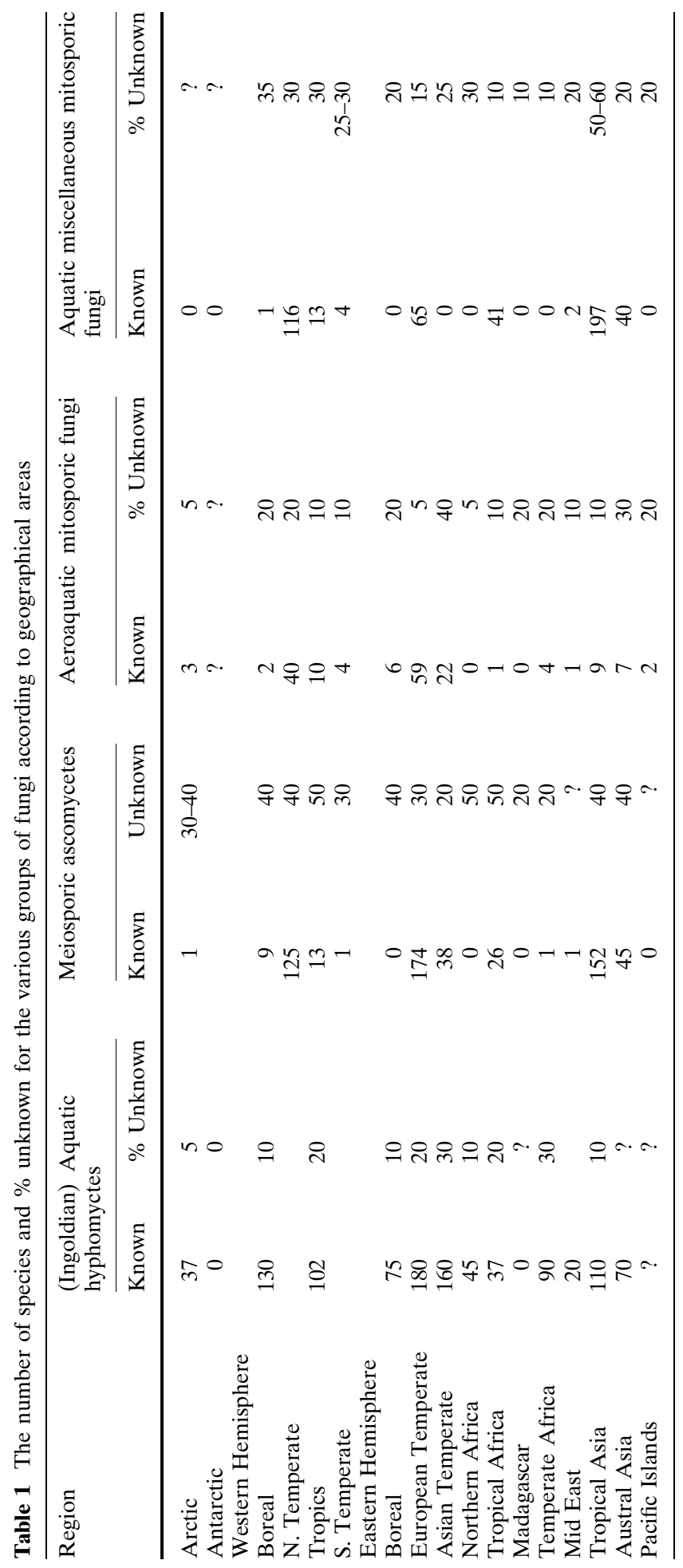




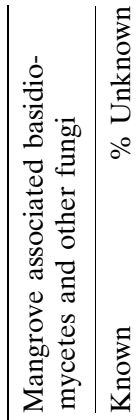

ㄷํ요

オーコのฎニ゚

ำ そ

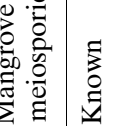

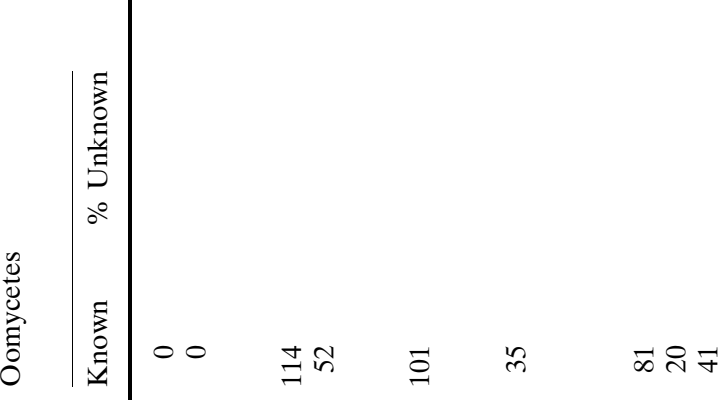

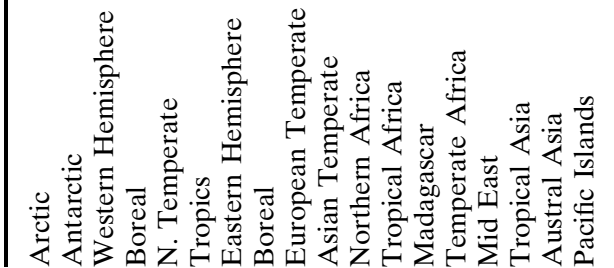


About 500 species of meiosporic euascomycete species have been reported from freshwater. This group consists of species of Discomycetes, Loculoascomycetes and Pyrenomycetes in a proportion of 111:143:246. When terrestrial ascomycete orders are considered (Barr 1987, 1990; Hawksworth et al. 1995; Eriksson 2004), current information suggests that certain evolutionary lines were more successful than others in adapting to freshwater habitats. Species representing only 18 of 46 ascomycete orders have been reported from fresh water. The orders represented by 10 or more species reported from fresh water are Helotiales (101 spp.), Pleosporales (91 spp.), Sordariales (114 spp.), Halosphaeriales (24 spp.), Melanommatales (30 spp.), Eurotiales (25 spp.), Xylariales (19 spp.), and Hypocreales (14 spp.).

About $70 \%$ of the ascomycetes reported from freshwater habitats have been reported from fresh water only once (Shearer 2002). Since so few geographical areas have been sampled, little can be said about the world distribution of species collected only once. Some of these species are known also from terrestrial habitats and their presence in water may be fortuitous. A significant number are new taxa described from the tropics, a relatively under-collected area (Hyde et al. 1997). It is likely that many of these species will be encountered again in future studies of tropical aquatic systems. It would be premature to suggest that any of the freshwater ascomycete species collected from only one locality are endemic.

The most concerted collecting efforts have occurred in Asia, Australia and North America. It is not surprising, therefore, that a considerable number of commonly occurring species occur within similar ranges in latitude at distant localities in the eastern and western hemispheres (Table 1). The highest diversities occur in temperate North America, the United Kingdom and Europe and tropical Austral Asia-the geographical areas that have been sampled most intensively. Some commonly occurring taxa appear to be distributed globally within certain latitudinal ranges. Some examples include Massarina ingoldiana, Aniptodera chesapeakensis, Aniptodera lignatilis, Annulatascus velatisporus, Halosarpheia retorquens and Nais inornata (Shearer 2001).

The polar zone is greatly under-collected so it is not known whether this zone has a distinctive freshwater ascomycota. Obtectodiscus aquaticus was described from alpine lakes in Switzerland and Austria and was collected on Carex and Eriophorum in the Alaskan tundra but has not been collected from any other geographical areas (Shearer 2002).

Hyde et al. (1997) suggest that a distinctive tropical freshwater ascomycota exists because most of the ascomycetes they have encountered in the tropics are new species or have not been reported from other climatic zones. Recently, a number of such "tropical" taxa have been reported from the Great Smoky Mountains National Park in temperate North America (Raja et al. 2004). There are a number of species, however, that occur in both the paleo- and new world tropics that have not been found outside of tropical localities. Additional collections along latitudinal gradients are needed to confirm the existence and composition of a distinctive tropical freshwater ascomycota.

\section{Aquatic hyphomycetes}

Aquatic hyphomycetes are broadly defined as anamorphic fungi typically with relatively large branched (often stauroform) and scolecoform conidia occurring mainly 
in lotic waters. Their common substrate is submerged decaying tree leaves and woody debris. The prevailing stauroform shape of conidia is believed to facilitate colonization of substrates by contacting the surface simultaneously on three points by arm tips (Webster 1959).

Stauroform and scolecoform conidia accumulate in foam occurring on water surfaces, and many species were originally isolated in pure culture and described from foam. Hence the origin of many species remains unknown and some may not be residents, but only immigrants or transients (Park 1972) in water. Stauro- and scolecoform conidial shapes are also relatively frequent within terrestrial hyphomycetes, occurring in the permanently or intermittently humid layer of forest plant litter. Here the presence of branches is believed to facilitate movement on thin water films on wet litter surfaces (Bandoni 1974).

Phylogenetically aquatic hyphomycetes are presumed to belong mainly to Ascomycota, with only a small percentage related to Basidiomycota. Teleomorph/anamorph connections proven through pure culture studies or relationships found by comparing DNA nucleotide sequences of mitosporic and meiosporic taxa reveal that 23 spp. of aquatic hyphomycetes with scoleco- or stauroform conidia are classified in 5 classes of the subclass Pezizomycotina, class Leotiomycetes, order Helotiales. Pezizomycetes and Orbiliomycetes each contain one species. The family Nectriaceae (Sordariomycetes) is the only pyrenomycete family whose anamorph taxa occur relatively frequently in aquatic habitats, though the typical branched conidial shapes apparently have not developed there. The prevailing shape is elongate sigmoid or sickle-shaped, a shape also appearing in some terrestrial genera like Cylindrocarpon and Fusarium which are also frequently isolated from submerged plant debris. Pleosporales are the only order of Loculoascomycetes that have mitosporic states in water. Six genera have been connected with aquatic mitosporic states. Basidiomycota appear far less often in water. Conidial states are restricted to Corticiaceae from the polyporoid clade with three mitosporic species, and Urediniomycetes with two mitosporic species.

Aquatic hyphomycetes are predominantly saprotrophs, but several taxa are capable of biotrophy (e.g. Mycocentrospora acerina, Gyoerffyella entomobryoides) or mycoparasitism (Crucella subtilis, Naiadella fluitans).

Most species have been reported from temperate regions. Actual knowledge about the distribution of these fungi is highly biased due to the uneven level of sampling in various geographical areas. Seasonal variation in species abundance also plays a role in the effectiveness of sampling. Temperate North America and Europe, the United Kingdom, Chile, Japan and Malaysia are relatively well sampled.

Early reports on stauroconidia in water appear in articles published by algologists who used to find them among plankton and who described them as algae (Perty 1852; Reinsch 1867, 1888). De Wildeman $(1893,1894,1895)$ was the first to recognize these forms as fungal propagules and provided the first descriptions of conidiogenous structures in water. Ingold (1942 and many following publications) discovered the typical substrate for these fungi-submerged tree leaves. He also described many new species. Kaushik and Hynes (1971) uncovered the ecological role that these fungi play in energy flow in running waters with mainly allochthonous input of organic matter.

The first survey of hitherto known taxa is by Nilsson (1964), followed by Dudka (1974, 1985a, b), Ingold (1975), Webster and Descals (1981), Tsui and Hyde (2003) and Marvanová (1997), who summarised tropical taxa. 


\section{Freshwater aeroaquatic mitosporic fungi}

Aeroaquatic fungi inhabit submerged plant litter in a variety of shallow stagnant to slow-flowing freshwater bodies. Typical habitats with a high diversity of aeroaquatic fungi include shallow woodland ponds and ditches. As an adaptation to this habitat, many aeroaquatic fungi can withstand prolonged periods of oxygen depletion and are quite tolerant against sulfide (Field and Webster 1983, 1985). However, aeroaquatic fungi cannot complete their life cycle on submerged substrates, as their dispersal units are only produced aerially above the water level. They are therefore dependent on periodical drying of their habitats. These dispersal units are the most conspicuous characteristic for the whole group. They consist of complicated, usually multicellular, structures of an astonishing morphological diversity which entrap air and are therefore extremely buoyant. Buoyancy is often enhanced by warts and hydrophobic encrustations, which are often only visible with scanning electron microscopy (SEM). Dispersal takes place on the water surface. Evolution of the aeroaquatic lifestyle has occurred independently many times. Most aeroaquatic fungi described are mitosporic Ascomycetes (ca. 80 species); only four aeroaquatic Basidiomycetes and one peculiar aeroaquatic oomycete are known.

The two main pioneer investigators of aeroaquatic hyphomycetes are Agathe van Beverwijk (The Netherlands), who also created the term aeroaquatic fungi (Beverwijk 1951), and Janet Glen-Bott (U.K.), both worked in the early 1950s. Although several aeroaquatic species were described and/or monographed prior to the work of van Beverwijk and Glen-Bott (e.g. Linder 1929 for the aeroaquatic genera Helicoon and Helicodendron in his monograph on helicosporous fungi), their ecological niche remained unnoticed. Van Beverwijk and Glen-Bott not only described several new aeroaquatic species; they also were the first who realized that the main habitat of these fungi was submerged litter in stagnant water bodies, which yielded a unique aeroaquatic fungal community. Their most important methodological improvement was targeted collection of submerged litter and subsequent incubation in moist chambers, which proved to be a very useful method for investigation of this group. The characteristic dispersal units are usually produced on litter spread out in moist chambers within several days and then they can be easily investigated.

Research on aeroaquatic fungi has received increased attention since the late 1970s when John Webster and collaborators started extensive taxonomical and ecological investigations. As a result, many new species were described, mainly from England. This stimulated research in other countries, and in the past 20 years knowledge of aeroaquatic fungi has significantly increased. Nevertheless, Europe, Japan and the Eastern USA still are the best investigated areas, and knowledge from other parts of the world remains fragmentary (Table 1).

\section{Miscellaneous freshwater mitosporic ascomycetes}

Miscellaneous freshwater mitosporic ascomycetes include hyphomycetes and coelomycetes exclusive of aeroaquatic and aquatic hyphomycetes. This group generally includes hyaline and dematiaceous hyphomycetes whose conidia are not distinctively modified for the aquatic environment. Four hundred and five species of miscellaneous mitosporic fungi have been reported from freshwater thus far (refer to 
Freshwater Ascomycete Database (http://www.life.uiuc.edu/fungi/) for a species list. Of the 405 species reported, only nine species belong to the class Coelomycetes. Such a low occurrence of Coelomycetes from freshwater habitats is noteworthy. What factors contribute to the low occurrence of Coelomycetes from freshwater habitats is not known at this time, but the low occurrence might reflect the lack of taxonomic specialists in this group working in aquatic habitats.

Miscellaneous mitosporic ascomycetes in freshwater occur mainly on decaying herbaceous plant material and woody debris. Submerged woody debris supports a higher species diversity of miscellaneous mitosporic ascomycetes although this may reflect a lack of study of herbaceous debris using techniques that would facilitate the discovery of species in this group. There is a higher ratio of miscellaneous mitosporic ascomycetes to meiosporic ascomycetes on submerged wood, which is indicated by the following studies from lentic (Shearer and Crane 1986; Hyde and Goh 1998a; Goh and Hyde 1999) and lotic habitats (Shearer 1972; Hyde and Goh 1997, 1998b, 1999; Hyde et al. 1998; Sivichai et al. 2000, 2002; Tsui et al. 2000; Kane et al. 2002). Goh and Tsui (2003) provide a taxonomic key to commonly occurring genera of freshwater aeroaquatic and miscellaneous mitosporic fungi.

Miscellaneous mitosporic ascomycetes can be classified into two main groups based on Park (1972), indwellers and immigrants. Species in several genera of freshwater mitosporic ascomycetes like Aquaphila (Goh et al. 1998a), Canalisporium (Nawawi and Kuthubutheen 1989), Camposporidium (Nawawi and Kuthubutheen 1988), Candelosynemma (Hyde and Seifert 1992), Clohiesyomyces (Hyde 1993), Conioscyphopsis (Goh and Hyde 1998), Elegantimyces (Goh et al. 1998b), Enridescalsia (Ruiz et al. 1998), Jeranium (Nawawi and Kuthubutheen 1992), Nidulispora (Nawawi and Kuthubutheen 1990), Paracryptophiale (Kuthubutheen and Nawawi 1994), and Yinmingella (Goh et al. 1997) may be classified as indwellers because they have been reported only from freshwater habitats. Whereas, species in genera such as Acrodictys, Acrogenospora, Arthrobotrys, Bactrodesmium, Berkleasmium, Brachysporiella, Cordana, Dictyosporium, Ellisembia, Spadicoides, Sporidesmiella, Sporoschisma, and Trichocladium can be classified as immigrants because they are reported frequently from terrestrial as well as freshwater habitats.

Very few genera of freshwater miscellaneous mitosporic ascomycetes (anamorphs) have a meiosporic ascomycete (teleomorph) connection. Only eight species of miscellaneous mitosporic ascomycetes have been connected to teleomorphs (Sivichai and Jones 2003).

Miscellaneous mitosporic ascomycetes have been reported from the Arctic (Canada), Western hemisphere-North temperate (USA), Southern temperate (Argentina), Tropical America (Cuba, Venezuela), Eastern hemisphere-European temperate (Austria, England, Hungary, Poland, and Spain), Tropical Africa (Brunei, The Seychelles, and South Africa), Middle East (Iraq), Tropical Asia (Hong Kong, India, Malaysia, Philippines, Singapore, Taiwan, and Thailand), and Australasia (Australia, and New Zealand) (Table 1). Regions such as South America, northern temperate Africa, the Middle East, and Pacific Islands have not been sampled for freshwater miscellaneous mitosporic fungi. There are many freshwater habitats in the aforementioned regions that are in urgent need of study due to increasing habitat destruction. 


\section{Mangrove fungi}

Mangrove forests are biodiversity "hotspots" for marine fungi. A recent literature review indicated that 625 fungal species (including both meiosporic and mitosporic forms) have been reported from mangrove environments (Schmit and Shearer 2003). Of these, 131 are from sediments or mangrove peat materials, and many of these species may not be restricted to marine environments. Approximately 200 of these species are considered to be obligate marine fungi. There are many factors that contribute to the biodiversity of fungi associated with mangroves, including a wide variety of substrates for fungi, and important environmental gradients, such as salinity. Furthermore, daily changes in sea level due to tides may provide further opportunities for niche differentiation. Substrates above the high tide level will be rarely exposed to seawater, but will be exposed to air and direct sunlight. Substrates found below the high tide zone, on the other hand, will sometimes or always be submerged in seawater and will be less exposed to air and sunlight. Studies in which the fungal communities along different points of this tidal gradient have been sampled have shown that there are differences in species composition and abundance (e.g. Hyde 1988, 1990a).

Fungi have been reported from mangrove forests since at least the 1920's (Stevens 1920), however intensive studies did not occur until much later. Extensive surveys have been carried out in the Caribbean and Pacific Islands (Kohlmeyer 1984; Volkmann-Kohlmeyer and Kohlmeyer 1993) and in South East Asia (Sarma and Hyde 2001). Probably many new species are yet to be described.

Mangrove fungi are notable for their extremely wide distribution, in every sense of the word. Many of the fungi that are commonly associated with mangroves can also be found on suitable substrates in non-mangrove environments (Kohlmeyer and Kohlmeyer 1979). Mangrove fungi have long been known to have very wide geographical distributions, often circum-tropical (Jones and Alias 1997). However, many species have a much more limited range. It is difficult to determine if further sampling will expand the known ranges of most species. Currently, more mangroveassociated fungi are known from South East Asia than from any other part of the globe (Schmit and Shearer 2003). Again, it is not possible to determine if this is a result of uneven sampling, or if this is due to the high plant diversity of South-East Asian mangroves compared to mangroves elsewhere.

Seventy-two plant species have been reported as hosts for mangrove fungi (Schmit and Shearer 2003). Individual fungal species are often found on a wide variety of host plants (Kohlmeyer and Kohlmeyer 1979). However, some fungi are often more common on some hosts than on others when the hosts grow near to one another (e.g. Hyde 1990b; Leong et al. 1991; Alias and Jones 2000).

There is a notable difference in the sexual state of fungi found on different types of substrates in mangrove forests. Woody materials are more commonly colonized by meiosporic ascomycetes than by mitosporic fungi. The few marine basidiomycetes found in mangrove forests mostly colonize wood (Kohlmeyer and VolkmannKohlmeyer 1991). Mitosporic fungi usually colonize leaves and other organic material in the sediment, such as fine roots (Schmit and Shearer 2003). Oomycetes of the genus Halophytophthora are frequently found on newly fallen leaves (Nakagiri 2000). 


\section{Marine meiosporic and mitosporic ascomycetes}

The field of marine mycology has a relatively short history. Although the first autochthonous marine fungus was described and illustrated about 150 years ago, serious collecting of fungi in marine habitats started with Barghoorn and Linder (1944) who described 25 species from submerged wood in New England and California. About 100 additional new species followed were reported by 1970, described mainly by Höhnk (Germany), Meyers (United States), Johnson (United States), Kohlmeyer (Germany), and Jones (Great Britain). Johnson and Sparrow published A Treatise On Fungi In Oceans And Estuaries in 1961. The monograph, Marine Mycology (Kohlmeyer and Kohlmeyer 1979) lists 209 filamentous species. Twelve years later the number had increased to 321 (Kohlmeyer and Volkmann-Kohlmeyer 1991), and after another 10 years the total was 444 species (Hyde and Pointing 2000). By 2003, 465 marine filamentous fungi had been described.

Marine fungi are an ecological group, belonging to a wide variety of families. Therefore, the generally accepted definition of a marine fungus is broad and based on the habitat: obligate marine fungi grow and sporulate exclusively in the marine or estuarine environment; facultative marine species may grow in marine as well as in freshwater (or terrestrial) habitats (Kohlmeyer and Kohlmeyer 1979). The best method to obtain marine fungi is to search for fruiting bodies or conidia directly on a substrate derived from the marine environment. Some investigators use plating techniques, by streaking out seawater, marine sediment, or marsh soil to obtain cultures of fungi. Such isolates cannot be considered marine, unless it is demonstrated that they can actually grow (and, possibly, reproduce) in the marine habitat. A case in point is Aspergillus sydowii, isolated from diseased sea fans and causing the disease in laboratory experiments (Geiser et al. 1998).

Filamentous marine ascomycetes grow on most organic substrates occurring in oceans and estuaries. Lignicolous species are found on driftwood, pilings, wooden boats, mangrove roots and trunks. Others decompose dying marsh plants, such as Juncus and Spartina. Fewer species are known as parasites or saprobes on algae. Even more rare are coral inhabiting fungi and submarine lichens or lichenoid associations, e.g. mycophycobioses. The latter are obligate symbioses between ascomycetes and large rhodophytes and phaeophytes (Kohlmeyer and Kohlmeyer 1979).

The biogeography of marine fungi is mainly determined by the temperature and salinity of the water. Therefore, assignment of marine fungal species to the traditional geographic regions used in this article for terrestrial fungi is not always possible. Hughes (1974) introduced five biogeographic, temperature-determined regions for the distribution of marine fungi, namely, Arctic, temperate, subtropical, tropical and Antarctic. Temperate, as well as tropical-subtropical species may occur in areas where different biogeographic zones meet, e.g. around Cape Hatteras, North Carolina (Boyd and Kohlmeyer 1982; Kohlmeyer 1983). The difficulty in using traditional geographic regions for marine fungi is also evident, for instance, in New Zealand (a component of mostly tropical Australasia) where Lintott and Lintott (1982) reported obligately temperate species, such as Digitatispora marina and Asteromyces cruciatus.

The deep sea is a habitat characterized by low temperatures and high pressures; it cannot be divided into geographic regions because of its characteristic physical features that are more or less uniform around the globe. So far, only five indigenous 
Table 2 Number of species of filamentous marine fungi from different geographical areas

\begin{tabular}{lcc}
\hline Filamentous marine fungi & & \\
\hline Region & Known & Undescribed \\
\hline Arctic & 28 & 1 \\
Antarctic & 4 & \\
WH Boreal & 1 & \\
WH N. Temperate & 164 & 83 \\
WH Tropics & 99 & \\
WH S. Temperate & 60 & \\
EH Boreal & 28 & \\
EH European Temperate & 139 & 4 \\
EH Asian Temperate & 47 & \\
EH Northern Africa & 25 & \\
EH Tropical Africa & 25 & \\
EH Indian Ocean Islands & 81 & 58 \\
EH Temperate Africa & 55 & 31 \\
EH Middle East & 22 & 18 \\
EH Tropical Asia & 182 & 164 \\
EH Austral Asia & 114 & 78 \\
EH Pacific Islands & 70 & 5 \\
\hline
\end{tabular}

marine filamentous fungi have been described from these waters (Kohlmeyer and Kohlmeyer 1979). The most common ascomycete from the deep sea appears to be Haligena unicaudata, which has been collected at depths between 100 and $1000 \mathrm{~m}$ in the Mediterranean, and in the Atlantic and Pacific Oceans (Kohlmeyer 1983).

Due to the "infancy" of marine mycology and the small number of specialists, little is known about the global diversity and distribution of fungi in marine habitats. The largest number of species appears to occur in temperate and tropical waters (Table 2). But this may be due to the fact that these areas have been studied most intensively. As evident from Table 2, the regions in special need of exploration for marine fungi, besides the deep sea, are the following: the Arctic, Antarctic, and the boreal region of the Western and Eastern Hemispheres. Logistics and high costs for collecting in these regions make it unlikely that the numbers will increase significantly in the near future. However, it can be expected that concentrated collecting efforts in more easily accessible regions could yield considerable numbers of heretofore un-recorded species.

More survey work must be done to fully document the biodiversity of mangrove associated fungi. In particular, many plants that are found commonly in mangroves have not been systematically surveyed for fungi. More host materials, particularly leaves and root material, need to be examined. Surveys need to be carried out in regions that have not been explored, particularly tropical Africa, South America, the United State's Gulf Coast, Australia and temperate mangroves worldwide. Finally, ecological studies that help explain patterns of diversity of mangrove associated fungi will help to guide further survey efforts.

\section{Oomycetes, Saprolegniales}

Saprolegniaceous protists are among the most ubiquitous aquatic microbes found on earth. They can be isolated easily from freshwater and non-saline soils and some extend into mesohaline regions of estuaries and even into full strength seawater. A number-principally species of Aphanomyces-are important plant pathogens and 
some are animal parasites causing periodic infections on such economically important organisms as fishes and crustaceans. The great majority, however, are saprotrophs whose contribution to nutrient cycling has never been quantified with precision. Literature describing their biology and systematics dates to the 1700's and encompasses contributions from five continents.

Systematic accounts of taxa historically have been based on the nature of their coenocytic growth habit, methods of asexual reproduction-almost all produce flagellated spores-and their oogamous sexual features. Among the most prolific contributors to the knowledge of their identification and ecology have been A. de Bary, N. Pringsheim, W. C. Coker, F. K. Sparrow, A. Guillermond, K. Cejp, T. W. Johnson, Jr., R. L. Seymour, S. Suzuki, and M. W. Dick. Their landmark contributions to the literature of this group are too numerous to list in this contribution.

The saprolegniaceous biota of North and South America and Europe has been surveyed more intensively than that of Africa, Australia, and the Atlantic and Pacific Islands and many new taxa doubtless await discovery. The greatest biodiversity appears to be found in tropical countries (Table 1).

Probably the greatest drawback to a fuller understanding of their ecological significance and biodiversity lies in the time and care required to identify individual species. Ten days or more are often required from initial isolation to species identification. It is my opinion that the ultimate solution to this dilemma and to an understanding of oomycete phylogeny lies in the exciting DNA sequencing and probing technology that is now being focused on this family.

\section{Overall biodiversity}

Approximately 3047 taxa have been reported from aquatic habitats thus far (Table 3). The largest taxonomic group of fungi in aquatic habitats is comprised of meiosporic and mitosporic Ascomycota, followed by the Chytridiomycota.

There are sources of overestimation of species biodiversity within and among habitats. Within aquatic habitats, we do not adequately know the meiosporic/mitosporic connections hence the same fungus may be counted twice, once as its meiosporic morph and a second time as its mitosporic morph. Synonymies among

Table 3 The number of species in various taxonomic groups commonly found in aquatic habitats

\begin{tabular}{ll}
\hline Fungi from aquatic habitats & \\
\hline Taxonomic group & Number of species \\
\hline Chytridiomycota & 576 \\
Freshwater meiosporic ascomycetes & 450 \\
Mangrove meiosporic ascomycetes & 612 \\
Marine meiosporic and mitosporic & 465 \\
$\quad$ ascomycetes & 290 \\
Ingoldian mitosporic fungi & 90 \\
Aeroaquatic mitosporic fungi & 405 \\
Miscellaneous mitosporic fungi & 138 \\
Saprolegniales & 11 \\
Basidiomycetes from freshwater habitats & 10 \\
Basdiomycetes from brackish and & \\
$\quad$ marine habitats & 3047 \\
Total number of taxa &
\end{tabular}


species also occur, probably in many cases due to the lack of published keys and compilations of species descriptions for this ecological group. Terrestrial species washed into aquatic habitats occasionally are collected and reported as aquatic. Among habitats, different taxonomic specialists may work at different ends of an ecotone and the same fungal species may be counted twice in the overall estimation of fungal diversity. For example, of the 405 miscellaneous mitosporic fungi reported from freshwater, 39 of the same species were reported from decaying wood in terrestrial habitats in a single geographical location (Wang 2001). It is highly likely that species from aquatic habitats in the tropics also occur in the tropical rainforest habitat due to the very moist conditions. For example, Aliquandostipite khaoyaiensis was first described from a tropical rainforest (Inderbitzin et al. 2001) but later reported from submerged wood in the tropics (Raja et al. 2005).

One way to minimize overestimation of the total number of fungal species generally would be to establish a central fungal geographical distribution database. Such a database would contain the names of all accepted species and their synonymies; geographical, habitat and substrate information; location of specimens, cultures and sequences; and literature citations. Of course, the usual problem of who would pay for the establishment, updating and maintenance of such a database exists.

The sources of underestimation of the number of aquatic fungal species probably far outweigh the sources of overestimation. Historically, too few mycologists have specialized in this ecological group and that trend persists today. The result is a grossly incomplete geographical, habitat and substrate coverage. In addition, very few thorough, long-term studies of habitats and/or substrates have been undertaken. Kohlmeyer and Volkmann-Kohlmeyer (2001) studied a single salt marsh plant, Juncus roemerianus, and sampled all parts of the plant regularly over many years. Thus far, they have reported 117 species from J. roemerianus, of which 48 species, 14 genera and one family are new to science. No other long term, in depth taxonomic studies have been made of individual aquatic macrophytes.

The type of fungi one collects from an aquatic habitat is very technique dependent (Shearer et al. 2004). Generally, an individual researcher uses one or two techniques for a single study, essentially ignoring all the species the techniques do not detect. This too is a source of underestimation.

The aquatic environment appears to have selected for particular morphologies that have adaptive value. Examples include the scolecosporous, staurosporous spore forms (mostly mitosporic) and the presence of gelatinous sheaths and unfurling and branched meiospore appendages that facilitate dispersal and attachment to substrates in water. Such adaptations may represent convergent evolution or evolution in parallel and they may mask phylogenetic relationships and lead to underestimation of biodiversity at the generic level and higher (Campbell and Shearer 2003). Also, when organisms are well adapted to their habitats morphologically, they may adapt to local physical-chemical conditions through changes in physiology. It is highly likely that cryptic species exist within many of the cosmopolitan species.

\section{Geographical distribution}

The geographical distributions of species diversity for each of the major groups of aquatic fungi are presented in Table 1. The greatest overall species diversity is for temperate regions. This trend runs counter to the latitudinal distribution patterns of 
most other organisms where biodiversity peaks at lower latitudes, i.e. the tropics (Rosenzweig 1995). A very important question that needs to be answered is whether the global distribution patterns for aquatic fungi are a reality or an artifact of the locations of the most intense collecting. This question can only be answered with more parallel studies along latitudinal gradients on different continents.

\section{Conclusions}

1. There will always be fewer fungal taxa in freshwater and marine habitats compared to terrestrial habitats due to: (a) the exclusion of most basidiomycetes, zygomycetes and lichens and (b) the lower species diversity of plant hosts in aquatic habitats, and (c) the physiological constraints of submersion in water, especially seawater.

2. Probably many new species remain to be described for several reasons: (a) large geographical areas remain to be sampled (S. America, Africa, Australia, China, boreal and tropical regions worldwide); (b) several groups have been studied only recently and much work remains to be done (marine and freshwater filamentous fungi); (c) convergent evolution in morphology may mask evolutionary relationships; and (d) cryptic species adapted to local environmental conditions may be common.

3. The greatest biodiversity is in temperate regions, followed by Asian tropical areas. This pattern probably reflects, in part, location of actively collecting systematists but it could also reflect a higher diversity in ecological niches due to seasonality in temperate regions.

4. Overlap may be relatively high between species in freshwater and terrestrial habitats but not between those in marine and freshwater and marine and terrestrial habitats.

5. The ability to more rapidly identify and report aquatic fungi would be greatly facilitated by the development of up-to-date illustrated keys and monographs and a centralized geographical database with accepted names and synonymies; geographical, habitat and substrate information for each taxon; locations of specimens, cultures and sequences for species; and literature citations for the foregoing types of information.

6. Population approaches and molecular data are needed to resolve phylogenetic relationships and cryptic species to fully assess aquatic fungal diversity.

Acknowledgments The following individuals are acknowledged for their respective contributions to this paper: H. A. Thornton and D. Porter (Chytridiomycota, Chytridiomycetes); C.A. Shearer (Freshwater Meiotic Ascomycetes); E. Descals and L. Marvanová (Aquatic Hyphomycetes); H. Voglmayr (Freshwater Aeroaquatic Mitosporic Fungi); H. A. Raja (Miscellaneous Freshwater Mitosporic Ascomycetes); J.P. Schmit (Mangrove Fungi); J. Kohlmeyer and B. Volkman-Kohlmeyer (Marine Meiosporic and Mitosporic Ascomycetes); and D. Padgett (Oomycetes, Saprolegniales).

\section{References}

Alias SA, Jones EBG (2000) Colonization of mangrove wood by marine fungi at Kuala Selangor mangrove stand, Malaysia. Fungal Diversity 5:9-21

Bandoni RJ (1974) Mycological observations on the aqueous films covering decaying leaves and other litter. Trans Japn Mycol Soc 15:309-315 
Barghoorn ES, Linder DH (1944) Marine fungi: their taxonomy and biology. Farlowia 1:395-467

Barr DJS (1980) An outline for the reclassification of the Chytridiales, and for a new order, Spizellomycetales. Can J Bot 58:2380-2394

Barr DJS (2001) Chytridiomycota. In: McLaughlin D, McLaughlin E, Lemke P (eds) The Mycota VII (Part A). Springer-Verlag, Berlin

Barr ME (1987) Prodromus to Class Loculoascomycetes. Amherst, Massachusetts

Barr ME (1990) Prodromus to non-lichenized, pyrenomycetous members of Class Hymenoascomycetes. Mycotaxon 39:43-184

Berger L, Speare R, Hyatt A (1999) Chytrid fungi and amphibian declines: overview, implications, and future directions. In: Campbell A (ed) Declines and disappearances of Australian frogs. Environmental Australia, Canberra, pp 21-31

Beverwijk AL van (1951) Zalewski's Clathrosphaera spirifera. Trans Br Mycol Soc 34:280-290

Boyd PE, Kohlmeyer J (1982) The influence of temperature on the seasonal and geographic distribution of three marine fungi. Mycologia 74:894-902

Cai L, Zhang KQ, Hyde KD (2003) Freshwater ascomycetes. In: Tsui CKM, Hyde KD (eds) Freshwater mycology. Fungal Diversity Press, Hong Kong, pp 275-324

Campbell J, Shearer CA (2003) Systematics of Halosarpheia based on morphological and molecular data. Mycologia 95:532-553

Descals E, Webster J (1984) Branched aquatic conidia in Erynia and Entomophthora-sensu-lato. Trans Br Mycol Soc 83:669-682

De Wildeman E (1893) Notes mycologiques. Fasc II. Annales of the Societe Belge Microscopie 17:35-68

De Wildeman É (1894) Notes mycologiques. Fasc III. Annales of the Societe Belge Microscopie 18:135-161

De Wildeman É (1895) Notes mycologiques. Fasc II. Annales of the Societe Belge Microscopie 19:193-206

Dudka IA (1974) Aquatic hyphomycetes of the Ukraine (in Ukrainian). Naukova Dumka, Kiev, $240 \mathrm{pp}$

Dudka IA (1985a) Ascomycetes, components of freshwater biocoenosis. Ukrainskyi Botanichnyi Zhurnal 42:86-95

Dudka IO (1985b) Aquatic fungi Imperfecti of the U.S.S.R (in Russian). Naukova Dumka, Kiev, $186 \mathrm{pp}$

Eriksson O (2004) Myconet: outline of the Ascomycetes. < http:://www.umu.se/myconet/curr/current.html >

Field JI, Webster J (1983) Anaerobic survival of aquatic fungi. Trans Br Mycol Soc 81:365-369

Field JI, Webster J (1985) Effects of sulfide on survival of aero-aquatic and aquatic hyphomycetes from stagnant water. Trans Br Mycol Soc 85:193-199

Geiser DM, Taylor JW, Ritchie KB, Smith GW (1998) Cause of sea fan death in the West Indies. Nature 394:136-137

Goh TK, Hyde KD (1996) Biodiversity of freshwater fungi. J Ind Microbiol 17:328-345

Goh TK, Tsui KM, Hyde KD (1997) Yinmingella mitriformis gen. et. sp. nov., a new sporodochial hyphomycete from submerged wood in Hong Kong. Can J Bot 76:1693-1697

Goh TK, Hyde KD (1998) A new hyphomycete genus Conioscyphopsis from wood submerged in a freshwater stream and a review of Conioscypha. Mycol Res 102:308-312

Goh TK, Hyde KD, Ho WH (1998a) Aquaphila albicans gen. et. sp. nov., a hyphomycete from submerged wood in the tropics. Mycol Res 102:587-592

Goh TK, Tsui KM, Hyde KD (1998b) Elegantimyces sporidesmiopsis gen. et. sp. nov. on submerged wood from Hong Kong. Mycol Res 102:239-242

Goh TK, Hyde KD (1999) Fungi on submerged wood and bamboo in the Plover Cove Reservoir, Hong Kong. Fungal Diversity 3:57-85

Goh TK, Tusi CKM (2003) Key to common dematiaceous hyphomycetes from freshwater. In: Tsui CKM, Hyde KD (eds) Freshwater mycology. Fungal Diversity Press, Hong Kong, pp 325-343

Hawksworth DL, Kirk PM, Sutton BC, Pegler DN (1995) Ainsworth and Bisby's dictionary of the fungi, 8th ed. CAB International, Oxon, UK

Ho YW, Barr DJS (1995) Classification of anaerobic gut fungi from herbivores with emphasis on rumen fungi from Malaysia. Mycologia 87:655-677

Hughes GC (1974) Geographical distribution of the higher marine fungi. Veroeffentilichungen des Instituts fuer Meeresforschung Bremerhaven Suppl 5:419-441

Hyde KD (1988) Observations on the vertical distribution of marine fungi on Rhizophora spp. at Kampong Danau mangrove Brunei. Asian Mar Biol 5:77-81 
Hyde KD (1990a) A study of vertical zonation of intertidal fungi on Rhizophora apiculata at Kampong Kapok mangrove, Brunei. Aquat Bot 36:255-262

Hyde KD (1990b) A comparison of the intertidal mycota of five mangrove tree species. Asian Mar Biol 7:93-107

Hyde KD, Seifert KA (1992) Tropical Australian freshwater fungi. III. Candelosynnema ranunculosporum, a new genus and species of synnematous hyphomycetes. Aust Syst Bot 5:401-405

Hyde KD (1993) Tropical Australian freshwater fungi. VI. Tiarosporella paludosa and Clohesyomyces aquaticus gen. et sp. nov. (Coelomycetes). Aust Syst Bot 6:169-173

Hyde KD, Goh TK (1997) Fungi on submerged wood in a small stream on Mt Lewis, North Queensland, Australia. Muelleria 10:145-157

Hyde KD, Goh TK (1998a) Fungi on submerged wood in Lake Barrine, North Queensland, Australia. Mycol Res 102:739-749

Hyde KD, Goh TK (1998b) Fungi on submerged wood in the Riviere St Marie-Louis, The Seychelles. S Afr J Bot 64:330-336

Hyde KD, Goh TK, Steinke TD (1998) Fungi on submerged wood in the Palmiet River, Durban, South Africa. S Afr J Bot 64:151-162

Hyde KD, Goh TK (1999) Fungi on submerged wood from the River Coln, England. Mycol Res 103:1561-1574

Hyde KD, Pointing SB (eds) (2000) Marine mycology. A practical approach. Fungal Diversity Press, Hong Kong

Hyde KD, Wong SW, Jones EBG (1997) Freshwater Ascomycetes. In: Hyde KD (ed) Biodiversity of tropical microfungi. Hong Kong University Press

Inderbitzin P, Landvik S, Abdel-Wahab MA, Berbee ML (2001) Aliquandostipitaceae, a new family for two new tropical ascomycetes with unusually wide hyphae and dimorphic ascomata. Am J Bot 88:52-61

Ingold CT (1942) Aquatic hyphomycetes of decaying alder leaves. Trans Br Mycol Soc 25:339-417

Ingold CT (1951) Aquatic ascomycetes: Ceriospora caudae suis n. sp. and Ophiobolus typhae. Trans Br Mycol Soc 34:210-215

Ingold CT (1954) Aquatic ascomycetes: discomycetes from lakes. Trans Br Mycol Soc 37:1-18

Ingold CT (1955) Aquatic ascomycetes: further species from the English Lake District. Trans Br Mycol Soc 38:157-168

Ingold CT (1975) An illustrated guide to aquatic and waterborne hyphomycetes (Fungi Imperfecti). Freshwater Biological Association Scientific Publication 30:1-96

Ingold CT, Chapman B (1952) Aquatic ascomycetes: Loramyces juncicola Weston and L macrospora nsp Trans Br Mycol Soc 35:268-272

James TY, Porter D, Leander CA, Vilgalys R, Longcore J (2000) Molecular phylogenetics of the Chytridiomycota supports the utility of ultrastructural data in chytrid systematics. Can J Bot 78:336-350

Jones EBG, Alias SA (1997) Biodiversity of mangrove fungi. In: Hyde KD (ed) Biodiversity of tropical microfungi. Hong Kong University Press, Hong Kong, pp 71-92

Johnson TW, Sparrow FK (1961) Fungi in oceans and estuaries. J. Cramer, Weinheim

Kane DF, Tam WY, Jones EBG (2002) Fungi colonising and sporulating on submerged wood in River Servern, UK. Fungal Diversity 10:45-55

Karling JS (1964) Synchytrium. Academic Press, New York

Karling JS (1977) Chytridiomycetarium Iconographia. J Cramer

Kaushik NK, Hynes HBN (1971) The fate of the dead leaves that fall into streams. Archiv Fur Hydrobiologie 68:465-515

Kohlmeyer J (1983) Geography of marine fungi. Aust J Bot Suppl Ser 10:67-76

Kohlmeyer J (1984) Tropical marine fungi. PSZNI Mar Ecol 5:329-378

Kohlmeyer J, Kohlmeyer E (1979) Marine mycology. The higher fungi. Academic Press, New York

Kohlmeyer J, Volkmann-Kohlmeyer B (1991) Illustrated key to the filamentous higher marine fungi. Bot Mar 34:1-61

Kohlmeyer J, Volkmann-Kohlmeyer B (2001) Biodiversity of fungi on Juncus roemerianus. Mycol Res 105:1411-1412

Kuthubutheen AJ, Nawawi A (1994) Paracryptophiale kamaruddinii gen. et. sp. nov. from submerged litter in Malaysia. Mycol Res 98:125-126

Leong WF, Tan TK, Jones EBG (1991) Fungal colonization of submerged Bruguiera cylindrica and Rhizophora apiculata wood. Bot Mar 34:69-76

Li JL, Heath IB (1993) Chytridiomycetous gut fungi, oft overlooked contributors to herbivore digestion. Can J Microbiol 39:1003-1013 
Linder DH (1929) A monograph of the helicosporous fungi imperfecti. Ann Missouri Botanical Garden 16:227-389

Lintott WH, Lintott EA (1982) Lignicolous marine fungi from New Zealand. Mari Ora 10:73-76

Longcore J (1996) Chytridiomycete Taxonomy since (1960). Mycotaxon 60:149-174

Longcore J, Pessier A, Nichols D (1999) Batrachochtyrium dendrobatidis gen et. sp. nov., a chytrid pathogenic to amphibians. Mycologia 91:219-227

Marvanová L (1997) Freshwater hyphomycetes: a survey with remarks on tropical taxa. In: Janardhanan KK, Rajendran C, Natarajan K, Hawksworth DL (eds) Tropical mycology. Science Publishers, Inc., U.S.A, pp 169-226

Nawawi A, Kuthubutheen AJ (1988) Camposporidium, a new phragmoconidial genus of hyphomycetes. Mycotaxon 32:161-167

Nawawi A, Kuthubutheen AJ (1989) Canalisporium, a new genus of lignicolous hyphomycetes from Malaysia. Mycotaxon 34:475-487

Nawawi A, Kuthubutheen AJ (1990) Nidulispora gen. nov., a hyphomycete genus with crateriform conidia. Mycotaxon 36:329-336

Nawawi A, Kuthubutheen AJ (1992) Jerainum triquetrum gen. et sp. nov., a new hyphomycete with muriform and appendaged conidia. Mycotaxon 45:409-415

Nakagiri A (2000) Ecology and biodiversity of Halophytophthora species. Fungal Diversity 5:153164

Nilsson S (1964) Freshwater hyphomycetes: taxonomy, morphology and ecology. Symbolae Botanica Upsalienses 18:1-130

Park D (1972) On the ecology of heterotrophic microorganisms in fresh water. Trans Br Mycol Soc 58:291-299

Perty M (1852) Zur Kenntniss kleinster Lebensformen. Bern

Pounds JA, Fogden LA, Michael PL, Foster PN, La Marca E, Masters KL, Merino-Viteri A, Puschendorf R, Ron SR, Sanchez-Azofeifa GA, Still CJ, Young BE (2006) Widespread amphibian extinctions from epidemic disease driven by global warming. Nature 439:161-167

Raja HA, Campbell J, Shearer CA (2004) Additional reports of freshwater lignicolous meiosporic and mitosporic euascomycetes from the Great Smoky Mountains National Park. Annual meeting of the Mycological Society of America, Asheville, North Carolina. Inoculum 55:32. Abstract

Raja HA, Ferrer A, Shearer CA (2005) Aliquandostipite crystallinus, a new ascomycete species from submerged wood in freshwater habitats. Mycotaxon 91:207-215

Reinsch PF (1867) Die Algenflora der mittleren Theiles von Franken. Abh Naturforschender Gesellschaft Nürnberg 1866:1-238

Reinsch PF (1888) Familiae Polyedriarum Monographia. Notarisia 3:493-516

Rosenzweig ML (1995) Species diversity in space and time. Cambridge University Press, New York, NY

Ruiz RFC, Guarro J, Mayayo E (1998) Enridescalsia, a new genus of conidial fungi from submerged leaves in Cuba. Mycol Res 102:42-44

Sarma VV, Hyde KD (2001) A review on frequently occurring fungi in mangroves. Fungal Diversity 8:1-34

Schmit JP, Shearer CA (2003) A checklist of mangrove associated fungi, their geographical distribution and known host plants. Mycotaxon 85:423-477

Shearer CA (1972) Fungi of the Chesapeake Bay and its tributaries III The distribution of woodinhabiting ascomycetes and fungi imperfecti of the Patuxent River. Am J Bot 59:961-969

Shearer CA, Crane JL (1986) Illinois fungi XI fungi and myxomycetes from wood and leaves submerged in southern Illinois swamps. Mycotaxon 25:527-538

Shearer CA (1993) The freshwater ascomycetes. Nova Hedwigia 56:1-33

Shearer CA (2001) The distribution of freshwater filamentous ascomycetes. In: Misra JK, Horn BW (eds) Trichomycetes and other fungal groups: Robert W Lichtwardt Commemoration. Science Publishers, Inc., Enfield, New Hampshire, USA, pp 225-292

Shearer CA (2002) Freshwater Ascomycetes Database. http://www.fm5web.life.uiuc.edu:23523/ ascomycete/

Shearer CA, Langsam DM, Longcore JE (2004) Fungi in freshwater habitats. In: Mueller GM, Bills GF, Foster MS (eds) Biodiversity of fungi: inventory and monitoring methods. Elsevier Academic Press, San Diego, CA, pp 513-532

Sivichai S, Hywel-Jones NL, Somrithhipol S (2000) Lignicolous freshwater Ascomycota from Thailand: Melanochaeta and Sporoschisma anamorphs. Mycol Res 103:729-735 
Sivichai S, Jones EBG, Hywel-Jones NL (2002) Fungal colonisation of wood in a freshwater stream at Tad Ta Phu Khao Yai National Park, Thailand. Fungal Diversity 10:113-129

Sivichai S, Jones EBG (2003) Teleomorphic-namorphic connections of freshwater fungi. In: Tsui CKM, Hyde KD (eds) Freshwater mycology. Fungal Diversity Press, Hong Kong, pp 259-274

Sparrow FK Jr (1960) Aquatic phycomycetes. University of Michigan Press, Ann Arbor

Stevens FL (1920) New or noteworthy Puerto Rican fungi. Bot Gazette 70:399-402

Trinci AP, Davies AR, Gull K, Lawrence MI, Nielson BB, Rickers A, Theodorou MK (1994) Anaerobic fungi in herbivorous animals. Mycol Res 98:129-152

Tsui CKM, Hyde KD, Hodgkiss IJ (2000) Biodiversity of fungi on submerged wood in Hong Kong streams. Aquat Microb Ecol 21:289-298

Tsui CKM, Hyde KD (2003) Freshwater mycology. Fungal Diversity Press, Hong Kong, 350 pp

Volkmann-Kohlmeyer B, Kohlmeyer J (1993) Biogeographic observations on Pacific marine fungi. Mycologia 85:337-346

Wang CJK (2001) Lignicolous hyphomycetes of New York: a preliminary report. Harvard Papers Bot 6:215-222

Webster J (1959) Experiments with spores of aquatic hyphomycetes. I. Sedimentation and impaction on smooth surfaces. Ann Bot NS 23:595-611

Webster J, Descals E (1981) Morphology, distribution and ecology of conidial fungi in freshwater habitats. In: Cole GT, Kendrick B (eds) The biology of conidial fungi, vol. 1. Academic Press, NY, pp 295-355 